\title{
The Rise of Private Passenger Transport Start-Ups in Brazil and Their Relationship with Unemployment
}

\author{
Daiane Rodrigues dos Santos
}

Alessandro da Silva Nunes

Kathleen Mendonça Vieira

Universidade Veiga de Almeida

R. Ibituruna, 108 - Maracanã, Rio de Janeiro - RJ, 20271-020, Brazil

\begin{abstract}
Private passenger transport has undergone changes and adaptations in the last 5 years with the rise of start-ups such as Uber, Cabify and 99, which offer their partners (drivers) an income opportunity. During this same period, Brazil experienced a constant increase in unemployed people. Seeking a solution to unemployment, workers found in private passenger start-ups an alternative. Therefore, despite the unfavorable economic scenario, start-ups had a great business opportunity with the unemployed, who until then had in their assets a durable good (automobile) and, for the most part, did not generate financial gain, thus enabling, the realization of the partnership between unemployed and start-up. From this scenario, for the grounding of the study, we use the State Space Models.The results were satisfactory and pointed out that in the modeling of the series containing the evolution of private passenger start-ups in Brazil, the component that represents the unemployed volume (explanatory variable) is statistically significant, corroborating similar studies already published.
\end{abstract}

Keywords: Private transport of passengers; Start-ups; Uber; Unemployment

\section{Introduction}

In the first half of the decade the concept of private passenger transport began to be debated in Brazil, initially with the entrance of Uber, the consumer questioned the traditional service provided by taxi drivers. With greater sophistication and work done by drivers who in the past have consumed traditional service, as they have been the only option for this type of service for years, the start-up has gained the trust of the market, bringing new start-ups of its kind and partners (drivers), who, for the most part, only sought to supplement their incomes. According to ViegasandLetra (2016) apud Lopes (2017), this insertion in the market was only possible on behalf of the technological advances previously made, which surpassed barriers of security reliability, such as banking, which already made transactions through technology. Between 2014 and 2017, the growth rate of unemployment in Brazil partially obeyed a constancy, with no decreasing, according to data provided by $\operatorname{IBGE}^{1}$ (Graph12). In the same period, according to Gonçalves (2016), the start-ups of private passenger transport reached an accelerated growth. Possibly due to the increase in this rate.

Despite the unfavorable economic scenario for the entrance of capital in the country, these start-ups had a great business opportunity with the unemployed, who until then had in their patrimony a durable good (automobile) and that, for the most part, did not generate financial gain. Therefore, in order to make the partnership between unemployed and start-up, it is necessary basically the car and its owner to be in conditions that meet the required for registration. As for example in Uber (private passenger transport application), according to Leal (2016), initially there is a selective stage of "partner" drivers, who undergo a psychological evaluation and in and sequence check possible criminal records, being mandatory for the driver to carry a driver's license stating that he performs a paid activity. The second check is the stipulation of a minimum condition of physical and legal quality for the registration of vehicles, which vary according to the category of service, but having as a common requirement, at least be model 2008, in addition to having four doors and air conditioning.

Previously to this scenario, the partners (drivers) met the initial proposal of these start-ups which was to generate a complementary source of income from this service provision. However, many of them began to occupy the niche of the unemployed and, together with others who were not yet providing this type of service, made it their main source of income. Thus, the growth of private passenger transport start-ups in Brazil is owed to the high level of unemployment generated in the country in the face of the economic scenario so far. Currently, according to the Inflation Report published by the Brazilian Central Bank (Banco Central do Brasil), unemployment has reached

\footnotetext{
${ }^{1}$ IBGE is the main provider of data and information in the country, which meets the needs of the most diverse segments of civil society, as well as the federal, state and municipal government agencies.
} 
rates of change that decrease, or at least remain stable. Based on this reasoning, what will be the response of the private passenger transport market to the scenario of job offers resuming?

There are many reasons for the rise of private passenger transport start-ups in Brazil, the advance of technology, the growing awareness of sustainable consumption, the precariousness of the locomotion system in most Brazilian regions, and unemployment among the population. This study aims to investigate the relationship with unemployment (rate of unemployment of the population).The discussion on this relationship is fundamental for the Brazilian economy. The generation of income for the population, the increase or maintenance of the agents' consumption, the greater circulation of coins and the improvement in the locomotion of national territory, are some of the benefits of the maintenance and growth of the start-ups of private passenger transport in the country. In this article, statistical methods were used to verify the influence of rising unemployment on the increase in private passenger transport start-ups in Brazil, in other words on their services. We understand that their growth was partly driven by the lack of job opportunities generated by the market during the economic crisis, causing the unemployed to choose to provide services, as drivers, in start-ups to informal work. For the fundamentals of the research we use the Models State Space.

According to the methodology applied, the seasonal factor pertinent to the volume in millions of Reais in personal accident insurance of passengers can be considered deterministic, being in the month of December its highest peak and February its lowest.In parallel, the vacancy rate in the last quarter of the analyzed years showed increases in relation to the first quarter of all years (2012 to 2019), indicating a possible seasonal movement. It should be noted that other reasons may be associated with this type of movement in the analyzed series. Two reasons to be considered are holidays and end-of-year festivities that increase the demand for urban transportation making the market more attractive to drivers. Still according to the modelling, the long-term component (The level) showed sharp growth over the period under review. Only in 2016 was there a sharper decline, it is worth noting that during this period several demonstrations ${ }^{2}$ and acts of violence against the private passenger transport service occurred throughout the country, which generated discomfort both for drivers and passengers.

In the bibliographic reference (second section) we will start by presenting the first subsection, with the concept of start-ups and the proxy, Passenger Personal Accident Insurance, used in obtaining data. In the second subsection we will deal with the rides system, which although not a paid activity, is directly related to start-ups since it is also a collaborative economy, a service currently already offered by them with the concept of private passenger transport. In the third subsection we will talk about unemployment, as it happened in Brazil throughout the period studied and about the labor conditions of the services provided by drivers. In the fourth subsection, we will explain the two related variables. Then in the third section, we will present the proposed model to investigate the relationship between the selected variables. Then, in the fourth section, we will apply the metrics to the database, and finally we will make the conclusion of the studies available.

\section{Theoretical Reference}

\subsection{Private passenger start-ups and competition}

As a reflection of a society that is becoming increasingly technological, according to Silva and Andrade (2016), the addition of information technology to private transport services has brought drivers and passengers closer together. This movement began with a major focus on young people, as they are more adept at such innovations. According to Berger et al. (2018), Uber, in London, presents the same trend, besides the fact that drivers are between 30 and 40 years old, however, with the success of the start-ups, this service has made its audience more and more diversified, in relation to the age group.

Through Graph 1, according to Anatel ${ }^{3}$, it's possible to notice that between 2009 and 2015 there was an accelerated growth in $3 \mathrm{G}$ internet access via mobile phones, and only from 2015 this number of accesses is becoming constant. This occurred due to the emergence of the 4G internet in 2014 which, in addition to following the increase in popularity of the internet, generated a displacement of consumers because it is a faster service than $3 \mathrm{G}$.

\footnotetext{
${ }^{2}$ Refer to the main information agencies in the country, such as: BBC, Folha de São Paulo, Estadão, O Globo, Correio Brasiliense and Veja Magazine.

${ }^{3}$ Anatel is the first regulatory agency to be installed in Brazil, in November 5th, 1997. Nowadays its mission is to regulate the telecommunications sector to contribute with the development of Brazil.
} 
Graph 1: Evolution of the Number of Access via 4G and 3G frequency.

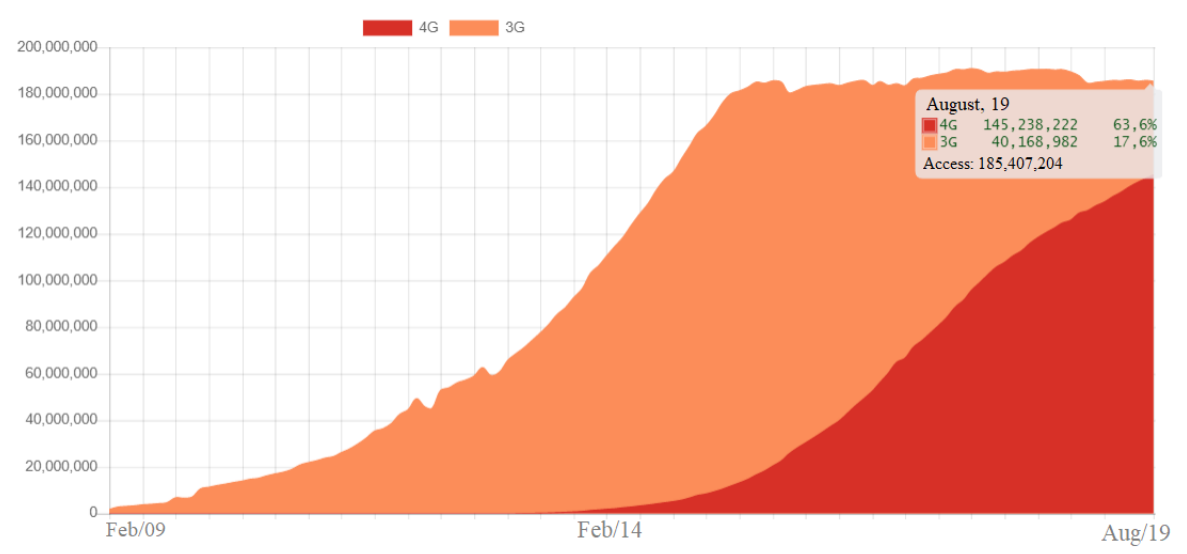

Source: Anatel

"The role of new technologies in the lives of individuals, both personal and professional, is impactful. In a globalized world the growing data traffic demands a continuous evolution of information technology, especially mobile telephony" (Godinho, p. 1, 2018, own translation). ${ }^{4}$

With the emergence of these applications, based on Lenz (2017), it is possible to call a car from where the user is and follow the entire route of the race in real time, in addition to knowing beforehand how much will be spent and be able to evaluate the quality of service provided once completed. The application also ensures greater security, having the option to share the trip with someone you trust. According to McAlone (2015) apud Pugliese (2016), "Touch a button, take a ride" ("Toque em um botão, pegueumacarona") is the most basic setting Uber allows. According to the author, anyone who has a smartphone, internet, and the "logged in" application set a starting location and ask for "a ride". The software program automatically sends an Uber driver to the selected location, from where the driver takes the customer to the destination. An interesting fact is that the drivers use their own cars, which means that "No vehicles avoids maintenance and fuel costs". In fact, the company only "develops, markets and operates the application".

According to a survey conducted by $\operatorname{eCGlobal}^{5}(2016)$ (Graph 2), more than half (64\%) of Internet users in Brazil with mobile devices use transportation service applications and almost 7 out of 10 respondents by the agency (66\%) used UBER. Among those who never used UBER, the most cited reasons were that they have not yet downloaded the application (32\%); prefer taxi services (26\%); use their own car for transportation (25\%) and do not have a credit card (16\%). As can be seen from Graph 2, 43\% of transport application users use Uber, ranking first among other applications. However, 36\% of the Brazilian Internet population does not have transport applications for users.

Graph 2: Partial result of the survey prepared by the Global EC in 2016.

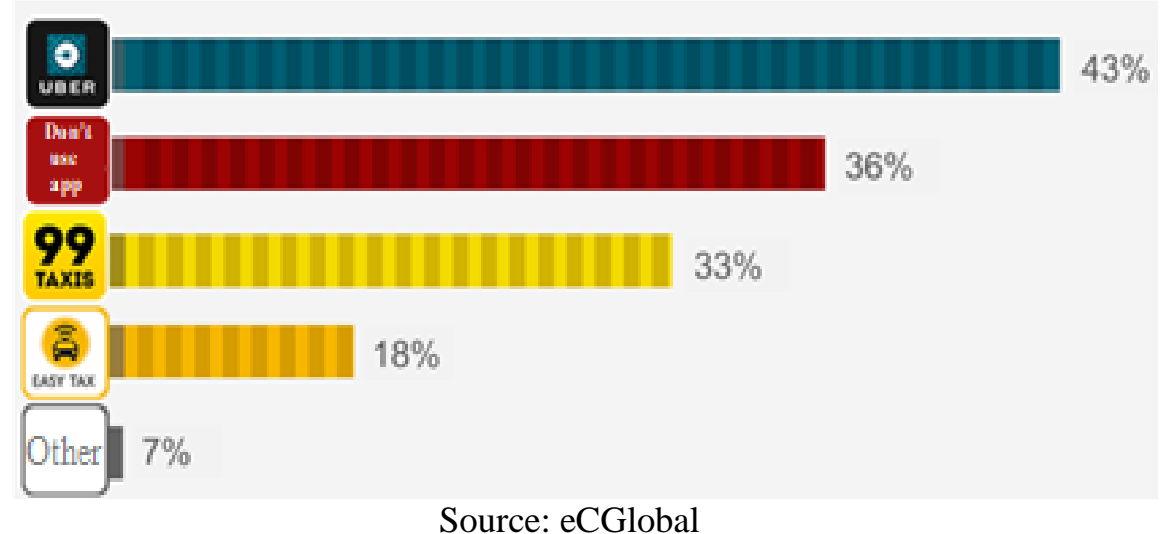

\footnotetext{
${ }^{4}$ Original Quote: “É impactante o papel das novas tecnologias na vida dos indivíduos, tanto pessoal quanto profissional. Em um mundo globalizado o crescente tráfego de dados demanda uma contínua evolução da tecnologia da informação, principalmente da telefonia móvel" (Godinho, p. 1, 2018).

5 eCGlobal is the international research platform of eCGlobal Solutions, specialized in research in America (Brazil, Mexico, Argentina, Colombia, Venezuela, Chile and the United States).
} 
Besides transportation by application, currently in Brazil, the most used means to perform day-to-day activities are: bus, subway, train, boats, car, motorcycle, bicycle and taxi. Considering the diversity of the Brazilian economic class, the start-ups of private passenger transportation are treated by a portion of the population as a complementary good. In accordance with Hall et al. (2018), Uber can be considered as complementary to public transport, this statement comes from the fact that most public transport systems use fixed routes with fixed schedules. Users are always looking for comfort and time optimization, so for those whose private means is economically feasible, Uber would be a valuable option. Nevertheless, there is always how to get somewhere using this public means of transportation.

The service provided by the Uber platform can also be considered a substitute good for the public transport service, for example. For Hall et al. (2018), while Uber's fares are typically higher than public transport fares, passengers will replace Uber with public transport if it is fast and convenient enough to compensate for its lack of attractiveness in the individual passenger service.

Graph 3: Number of users of private transport applications in Brazil in 2018 (in millions)

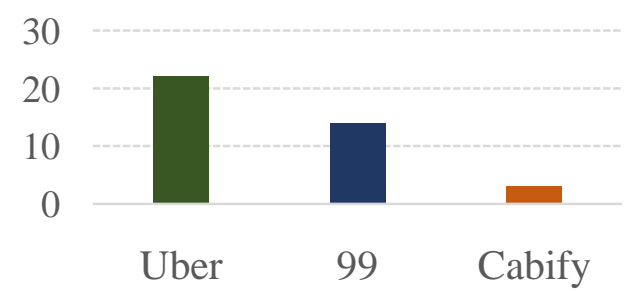

Source: Statista

Based on the number of users, according to Statista ${ }^{6}(\mathrm{Graph} 3)$, in the ranking of the main private transportation applications in Brazil in 2018, Uber ranked first with about 22 million users in the country, followed by the Brazilian application 99 which reached at least 14 million people. The search for the applications over the period from January 2012 to January 2019 can be seen in the graphs provided by Google Trends ${ }^{7}$ (Graphs 4, 5, 6 and 7), in which the popularity of the start-ups is measured through Google searches. Uber shows a positive constancy as its competitors permeate between great variations of its popularities. However, 99 manages to remain present in the market with the availability of two services, taxi and pop. By contrast, the Cabify app is steadily declining in popularity, as unlike the other two, your company does not offer insurance to partner drivers, meaning it must be contracted out, as stated in "Clause Three - Obligations and Responsibilities Driver's License "of Cabify's terms and conditions of use in Brazil. This is a factor of great relevance to justify this fall and, consequently, the low availability of vehicles, having a smaller coverage area when compared to its competitors.

Graph 4: Interest of Brazilians over time in applications
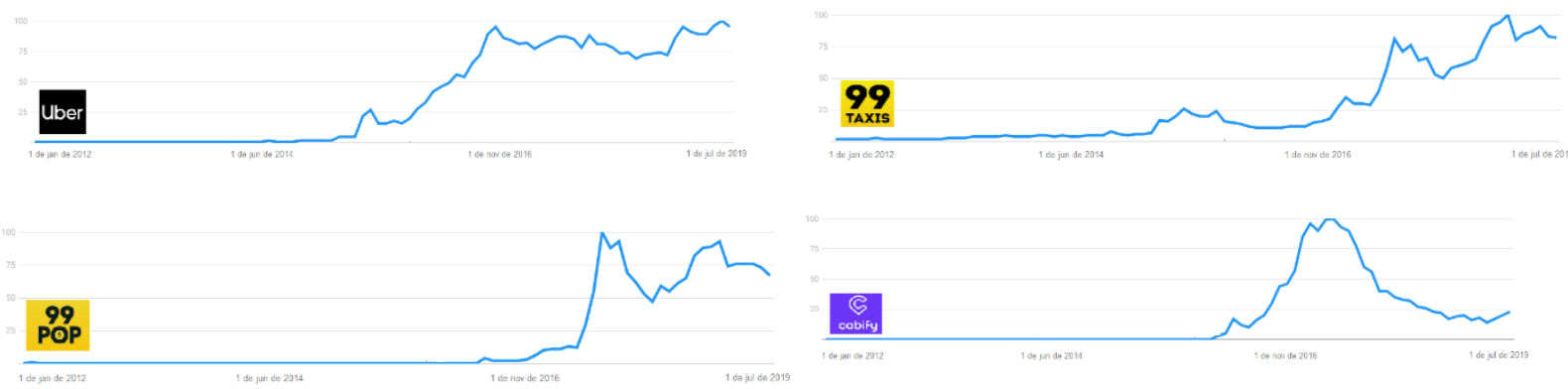

Source: Google Trends

Graph5: Evolution of Uber, EasyTaxi and 99Taxis popularity in Brazil, 2014-2017

\footnotetext{
${ }^{6}$ Statista is a German online portal for statistics, which provides data collected by market and opinion research institutes and data derived from the economic sector and official statistics available in English, French, German and Spanish.

${ }^{7}$ Google Trends is a Google tool that reports the popularity behavior of search terms on the site in each period. In the available graphs, the numbers represent the search interest relative to the highest point in the graph of a given region in each period. A value of 100 represents the peak in popularity of a term. A value of 50 means that the term was half as popular. A score of 0 means that there was not enough data on the term.
} 


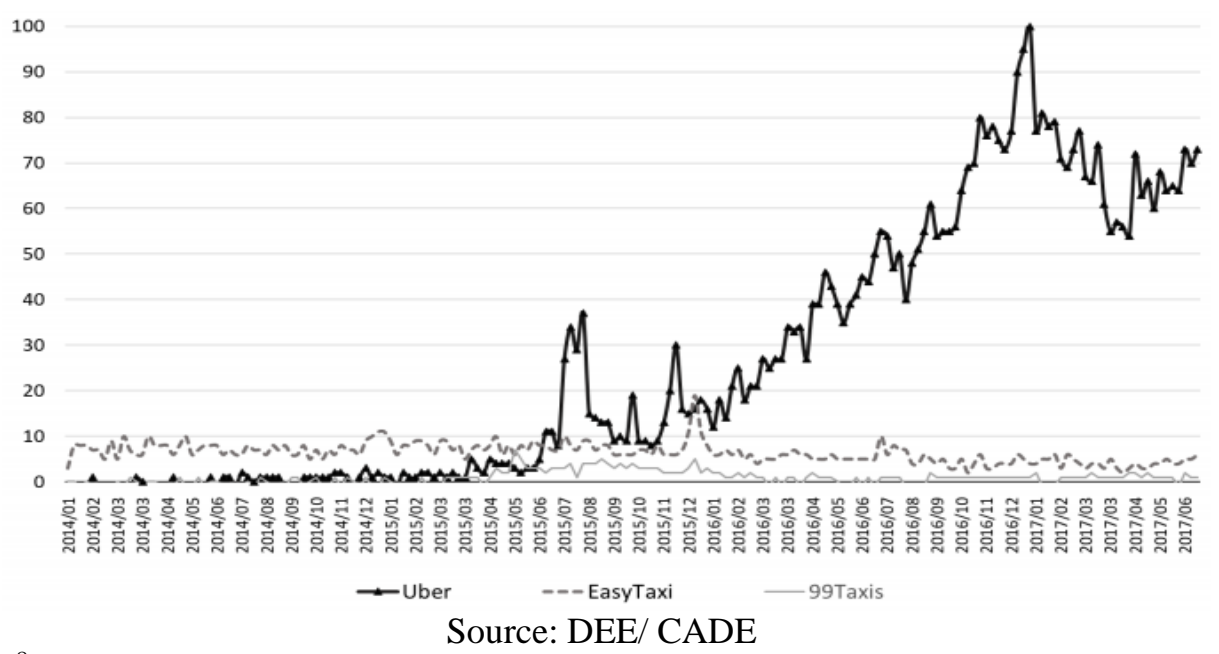

According to $\operatorname{CADE}^{8}(2018)$ (Graph5), Uber's popularity has grown significantly in the country, with a peak in December 2016, and as of 2017 several factors have helped explain the platform's success, including connection efficiency for both passengers and drivers, ease of paying for tours, diffusion of smartphones, and low prices. It is worth noting that the great advantage brought by hitchhiking applications is the reduction in costs, which increases the number of economic agents in the market and, consequently, the popularity of the application.

Based on a survey conducted in September 2017 using personal collection, by CNDL and SPC Brasil, with consumers from the 27 Brazilian state capitals, the new platforms per application took advantage over taxis in many of the categories surveyed. According to the interviewees, moving around using application-based transportation services is more common than ordering a taxi mainly for leisure activities such as going to bars, restaurants, movies, parties and parks.

Figure 1 shows the popularity of applications in the Brazilian states in June 2019. The data allow us to evaluate the territorial participation of private passenger transport start-ups. The shade of blue shows the popularity of start-ups in sub-regions. The more intense the shade, the greater the interest of the agents in the subject.

Figure 1: Popularity of applications in Brazilian states in June 2019.
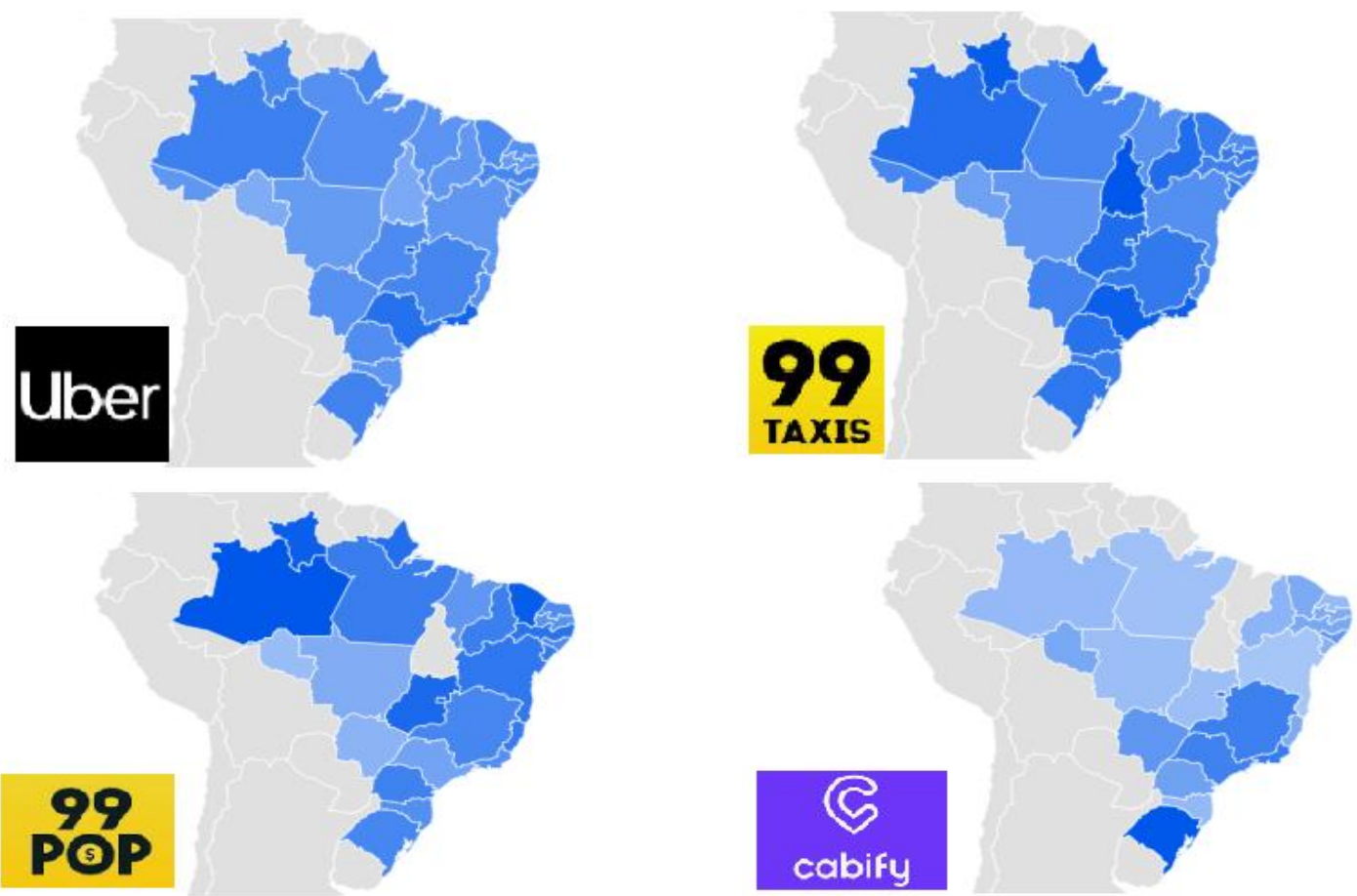

Source: Google Trends

\footnotetext{
${ }^{8}$ CADE is a federal autarchy, linked to the Ministry of Justice, with headquarters and jurisdiction in the Federal District, which exercises, throughout the national territory, the attributions given by Law 12.529/2011. Its mission is to ensure free competition in the market, being the entity responsible, within the Executive Branch, not only for investigating and deciding, ultimately, on competition matters, but also to foster and disseminate the culture of free competition.
} 
As can be seen in Figure 1, although Uber start-up is popular throughout most of the country, the sub-regions with the most interest are: Brasília, Rio de Janeiro, São Paulo and Amazonas. The 99 taxi start-up showed more interest in the regions: Tocantins, Roraima, Rio de Janeiro and São Paulo. According to the map provided by Google Trends, in June 2019, agents search for the 99 pop app with greater intensity in Amazonas, Ceará, Roraima and Distrito Federal. The Cabify start-up, in the period analyzed, showed more interest in the sub-regions: Rio Grande do Sul, Distrito Federal, Rio de Janeiro and Minas Gerais.

When it comes to market laws, the restrained demand for quality transportation of the Brazilian has been met by private services, taking into consideration those who can pay for this type of service. For the equation of urban mobility to be extended to all and ensure attributes such as efficiency, safety and ecological awareness, there is still a need for public policies and concrete investments that encourage quality public transport, modal integration and better planning of public space occupation (CNDL/SPC BRASIL, 2017).

The availability of data on the studied variable is a factor that measures the rise of transport start-ups in the country. The solution found was to use the passenger personal accident insurance data provided by SUSEP, since for these transports to be available to the population the insurance is mandatory.

\subsubsection{Personal accident insurance for passengers - as a proxy for the volume of private passenger transport start-ups in Brazil}

For this article, data were collected from organs with great credibility, thus seeking a reliable analysis of reality. IBGE, being the source used in the correlated unemployment factor, in private passenger transport, the required body was the SUSEP (Private Insurance Superintendence), because it is a private insurance, it is responsible for the control and supervision, having been created by Decree-Law No. 73 of November 21, 1966, as stated on its website.

According to SUSEP (2019), the purpose of this Insurance is the compensation for damages resulting from personal accidents to passengers, when carried in vehicles for private or public use and intended for this purpose. Personal accident is considered the event with a characterized date, of external origin, sudden, involuntary and violent, causing physical injury that, by itself and independent of any other cause, has as direct consequence the death, total or partial permanent disability of passengers or makes medical treatment necessary.

According to Uber (2019) and 99 (2019), it can reach $\mathrm{R} \$ 100,000.00$ (Brazilian Currency)depending on what can happen. This insurance covers partner drivers from the moment they travel to pick up their passengers, and passengers from the moment they board the trip until the moment it is closed. Cabify (2019), on the other hand, requires each driver to purchase the insurance on an individual basis, which means it is the partner's responsibility, and if not, the partner is unable to provide this type of service. Another requirement is that this insurance has a minimum premium of $\mathrm{R} \$ 50,000.00$ per passenger, material damage to the vehicle, damage to third parties (RCF-V - Optional Civil Liability of vehicles).

From data provided by SUSEP, this article studies the increasing volume of drivers entering this market. And, therefore, the relationship of this growth with the rise in the unemployment rate.

In the period covered by the time series ( 83 months), 33 companies were hired to provide services, among which the partners of the start-ups responsible for private passenger transport stand out most, thus justifying the use of data provided by SUSEP.

\subsection{Ride System}

"Every day people interact with the collaborative economy - traditional sharing, bartering, lending, negotiating, renting, giving and exchanging - redefining through technology and peer communities. This economy allows people, besides realizing the benefits of access to products and services over property, to save money, space and time, make new friends and become more active citizens" (Figueira, 2015, p:7, own translation). ${ }^{9}$

Population growth (Graph 6) has triggered several social and environmental problems, among them the increase in consumerism and the great environmental pollution offered by means of transportation, as a consequence of the large number of vehicles passing through the streets that, in addition, generate traffic jams, thus returning to social problems.

\footnotetext{
${ }^{9}$ Original Quote: "Todos os dias pessoas interagem com a economia colaborativa - compartilhamento tradicional, escambo, empréstimo, negociação, locação, doação e troca - redefinindo por meio da tecnologia e de comunidades entre pares. Esta economia permite que as pessoas, além de perceberem os benefícios do acesso à produtos e serviços em detrimento à propriedade, economizem dinheiro, espaço e tempo, façam novos amigos e se tornem cidadãos mais ativos" (Figueira, 2015, p:7).
} 
Graph 6: Total population from 2014 to 2024 (in millions)

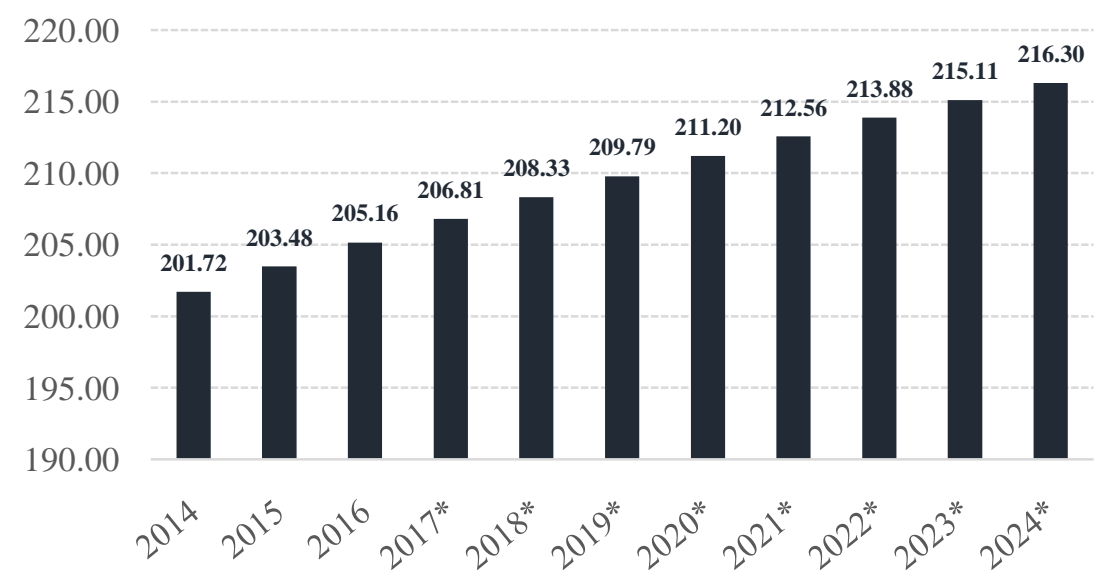

Source: Statista

According to Statista (Graph 6), Brazil's population between the years 2014 and 2016 had a linear growth, which made it possible to estimate up to 2024 an expected 216.5 million inhabitants. This has a direct impact on sustainable technology, whose advance is increasingly necessary to fulfill demands.

In order to meet the needs such as cost reduction and sustainability, there is the proposal of rides. This system reduces the environmental impacts, considering that a car with five seats, where each could be in a different, having the reduction of four vehicles, would thus optimize the space. In addition, the money that would be spent on fuel could be split for all passengers, reducing spending.

The article Evaluating the Effect of Car-Sharing, defines that studies on car sharing in the United States

"[...] generates eventual impacts on the way we travel, where each new shared vehicle eliminates the use of 3 to 20 cars and reduces driving time by 20 to 40 percent" (Tal, 2009, apudFigueira, 2015, p.4, own translation). ${ }^{10}$

This rides system is part of the collaborative economy. According to Botsman and Rogers (2011) apudFigueira (2015), the term is a way to accommodate the desires and needs of consumers in a more sustainable and attractive way with less burden to the individual. This economic model provides people with financial, space and time savings as well as the creation of new bonds.

"Common goods are a new paradigm for creating value and organizing a community of shared interests" (Bollier, 2009, apudFigueira, 2015, p.9, own translation). ${ }^{11}$

Although this seems the perfect solution to the current problems faced, many people are not adept at rides. There is a part of the population that does not give up its privacy. Currently, there are applications aimed at this system, but some claim lack of security because they do not know the others present in the vehicle. Many young university students use this scheme in their daily academic journey, as they are usually riding groups formed by the students themselves, in which everyone already knows each other. There are also those who take the risk because of the great difference in value when traveling from one state to another, for example, usually representing the portion of the low-income population.

"People of lesser income and age have greater acceptance. Other issues such as the route taken by the driver and his flexible hours also influence this acceptance" (Junior and Fusco, 2013, p.3, own translation). ${ }^{12}$ Uber $\quad$ has $\quad$ as a possibility the "together" mode that is characterized by sharing the trip with other passenger(s). By selecting this option, the user indicates how many seats you require and the application takes care of finding, through algorithms, other passenger(s) who have a destination close to theirs, reducing the cost of the trip. However, as with rides, this returns to the uncertainty factor.

\footnotetext{
${ }^{10}$ Original Quote: “[...] geram eventuais impactos na maneira de viajar, onde cada novo veículo compartilhado elimina o uso de 3 a 20 carros, e reduz o tempo de condução por cerca de 20 a 40 por cento" (Tal, 2009, apud Figueira, 2015, p.4).

${ }^{11}$ Original Quote: "Os bens comuns são um novo paradigma para criar valor e organizar uma comunidade de interesses compartilhados" (Bollier, 2009, apud Figueira, 2015, p.9).

12 Original Quote: "Pessoas de menor renda e idade têm maior aceitação. Outras questões como o trajeto realizado pelo motorista e a sua flexibilidade de horário também influenciam nessa aceitação” (Junior e Fusco, 2013, p.3).
} 
"It is considered the safest route because the driver is not alone, but the ride among strangers can generate just the opposite, that is, the feeling of insecurity. This, together with cultural issues, makes it difficult for the Brazilian population to accept the practice of shared transport on a larger scale" (Bianchi, 2015, p.20, own translation). ${ }^{13}$

\subsection{Unemployment and working conditions}

For a country where the economic scenario is unfavorable, unemployment is a fact that causes great concern, as it can mean a fall in the circulation of money, causing instability in the economy.

For Pinho (1998) apud Ribeiro (2015), the unemployment rate has an evaluation index on labor market imbalances, demonstrating the inability of the economic system to organize a productive occupation for workers. According to the National Continuous Household Sample Survey (Pesquisa Nacional por Amostra de DomicíliosContínua ) (Table 1) published by IBGE in April 2019, in the first quarter of 2019 the vacancy rate was estimated at 12.7\% (Table 1 and Graph 10) for the mobile quarter from January to March 2019, registering a variation of 1.1 percentage points over the quarter from October to December 2018 (11.6\%). In comparison with the same mobile quarter of the previous year, January to March 2018, when the rate was estimated at 13.1\%, the figure was down (0.4 percentage points).

"[...] the year 2014 registered the lowest unemployment rate in the period, so this increase occurred in the years 2015 and 2016. In these years Brazil went through a recessive process characterized by greater indebtedness, reduction of investments, associated with the political crisis, as well as reduction of output and household consumption, which reflected in job losses and deterioration of structural results of the labor market" (Pereira et al., 2018, p.18, own translation). ${ }^{14}$

Table 1: Vacancy Rate - Brazil - 2012/2019

\begin{tabular}{l|l|l|l|l|l|l|l|l}
\hline & 2012 & 2013 & 2014 & 2015 & 2016 & 2017 & 2018 & 2019 \\
\hline nov-dec-jan & & 7.2 & 6.4 & 6.8 & 9.5 & 12.6 & 12.2 & 12.0 \\
\hline dec-jan-feb & & 7.7 & 6.7 & 7.4 & 10.2 & 13.7 & 12.6 & 12.4 \\
\hline jan-feb-mar & 7.0 & 8.0 & 7.2 & 7.9 & 10.9 & 13.7 & 13.1 & 12.7 \\
\hline feb-mar-apr & 7.7 & 7.8 & 7.1 & 8 & 11.2 & 13.6 & 12.9 & \\
\hline mar-apr-may & 7.6 & 7.6 & 7 & 8.1 & 11.2 & 13.3 & 12.7 & \\
\hline apr-may-jun & 7.5 & 7.4 & 6.8 & 8.3 & 11.3 & 13 & 12.4 & \\
\hline may-jun-jul & 7.4 & 7.3 & 6.9 & 8.5 & 11.6 & 12.8 & 12.3 & \\
\hline jun-jul-aug & 7.3 & 7.1 & 6.9 & 8.7 & 11.8 & 12.6 & 12.1 & \\
\hline jul-aug-set & 7.1 & 6.9 & 6.8 & 8.9 & 11.8 & 12.4 & 11.9 & \\
\hline aug-set-oct & 6.9 & 6.7 & 6.6 & 8.9 & 11.8 & 12.2 & 11.7 & \\
\hline set-oct-nov & 7. & 6 & 6.5 & 8.9 & 11.8 & 12.0 & 11.6 & \\
\hline oct-nov-dec & 6.9 & 6.2 & 6.5 & 8.9 & 12 & 11.8 & 11.6 & \\
\hline
\end{tabular}

Source: IBGE

\footnotetext{
${ }^{13}$ Original Quote: "Considera-se o trajeto mais seguro pelo fato do motorista não estar sozinho, porém, a carona entre desconhecidos pode gerar justamente o oposto, ou seja, a sensação de insegurança. Esta, aliada a questões culturais, dificulta a aceitação da população brasileira à prática do transporte compartilhado em maior escala" (Bianchi, 2015, p.20).

${ }^{14}$ Original Quote: “[...] o ano de 2014 registrou a menor taxa de desemprego no período, portanto, o aumento desta taxa se deu nos anos de 2015 e 2016. Nestes anos o Brasil passou por um processo recessivo caracterizado por maior endividamento, redução dos investimentos, associados à crise política, bem como redução do produto e do consumo das famílias, o que refletiu em perdas de emprego e deterioração dos resultados estruturais do mercado de trabalho" (Pereira et al. ,2018, p.18).
} 
Graph 7: Unemployment rate for people 14 years and older, in the reference week of the quarters from January to March - Brazil - 2012/2019 (in \%)

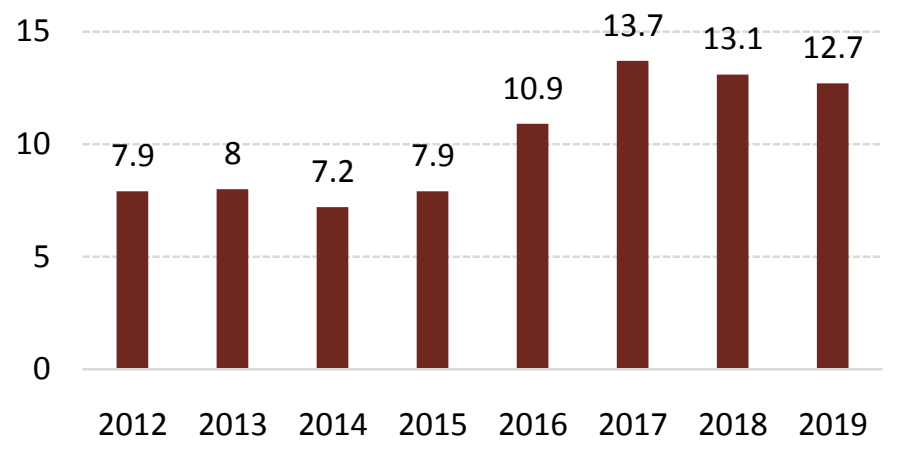

Source: IBGE

Seeking a temporary solution to unemployment, workers have found an alternative in private passenger transport start-ups. However, already with the adaptation to the work done, financial yield achieved and thus becoming the main source of income for them, doubts about working conditions were called into question, about the time loads, security (in the face of public violence and its competitors, taxi drivers, for regulatory reasons) and operational failures of the system, such as GPS, which wrongly indicated the location of passengers and routes to be traveled, again putting at risk the security of its partners and users.

"The transformations and changes that society has been experiencing are impossible to ignore, organizations and workers need to adapt to this new reality to ensure their survival [...]" (Leite, 2015, apudLopes, 2017, p.9, own translation). ${ }^{15}$

This is how the start-ups enter the transport market, which for Romero and Sosa (2016), is the emergence of a new profile of drivers, classified as autonomous and representing the middle class. They are responsible for the working hours and schemes, far from the traditional parameters, making it an attractive and flexible business for both the company and the partner. However, according to Castro (2017), taking Uber as an example, there is a working relationship that is vertical between employer and worker, drivers only work for the brand and are not bound to ownership of the company's assets and liabilities.

For Vaclavik and Pithan (2018), there is a still not very well-established formalization in the service provision practiced by drivers, which is inherent in the formation of new jobs, where the regulations need to be reviewed. The main issue addressed with great fear by the drivers is safety, which currently has a measure following incidents and crimes, through the Personal Accident Insurance for passengers, regulated by SUSEP.

\subsection{Private passenger transport start-ups and unemployment}

According to Rodrigues (2016), low salaries in Brazil are a favorable factor for start-ups that initially sought to meet a complementary income,

[...]if everyone earns less, everyone buys less, everyone sells less and everyone produces less, decreasing the profit mass of the economy and, particularly as a result of diseconomies of scale, increasing costs, decreasing competitiveness and consequently rising unemployment (Reinert, 2012, apud Ribeiro, 2015, p.265, own traslation), ${ }^{16}$ yet that was not the pillar of their growth. During unemployment generated by the economic/political crisis, the search for a source of income generates a reaction from the working class that displaces its workforce to illegal trade. This explains Maia (2001) apud Pereira et al. (2018), when he examined the structure of unemployment and the demand for work in metropolitan Brazil in relation to the years 1983-1998, which classified this movement as a gain for the informal market, which received a more qualified workforce.

\footnotetext{
${ }^{15}$ Original Quote: “As transformações e mudanças que a sociedade vem vivendo são impossíveis de serem ignoradas, as organizações e trabalhadores precisam se adaptar a esta nova realidade para garantirem sua sobrevivência [...]" (Leite ,2015, apud Lopes ,2017, p.9).

${ }^{16}$ Original Quote: [...]se todos ganham menos, todos compram menos, todos vendem menos e todos produzem menos, diminuindo a massa de lucro da economia e, particularmente em função das deseconomias de escala, aumentam os custos, diminui a competitividade e, consequentemente, aumenta o desemprego (Reinert, 2012, apud Ribeiro, 2015, p.265),
} 
Nevertheless, with the entry of start-ups in the private passenger transport market, the unemployed observed a legal opportunity to raise income. In other words, the growth of start-ups in Brazil accompanies the rise in unemployment rates. According to Adrianse (2016), Uber can be treated as an "adequate income generating opportunity" due to high levels of unemployment. But also, for Means and Seiner (2016), the opportunity to work in a transportation start-up, in a way, can protect workers who are already employed, since it generates an additional income for their temporal economic activity, and is largely beneficial.

For Ribeiro et al. (2018), the average net profit of a driver in the month working 44 hours per week corresponds to $\mathrm{R} \$ 1,100.00$. In addition, as a complementary income model and disregarding the fixed costs of the vehicle, a double worker would obtain up to $70 \%$ of a minimum wage as extra income for each week of 10 hours of work. However, many partners use this service provision as their main source of income because of unemployment, thus increasing monthly earnings.

As mentioned above, this study proposes to investigate the relationship between the rise of start-ups in Brazil and unemployment (rate of unemployment of the population) in the same period. To support the study, we use the Models State Space.The results were used to verify the premises that motivated the preparation of this study.

\section{State Space Model}

In structural models, a time series can be broken down into components of interest, such as trend, seasonality and cycle, and can be modeled as a function of its own past or of other variables.

$$
\begin{aligned}
& \text { In this article the following structural model will be used. } \\
& y_{t}=\mu_{t}+\gamma_{t}+\beta X_{t}+\varepsilon_{t}, \quad \varepsilon_{t} \sim N\left(0, \sigma_{\varepsilon}^{2}\right) \\
& \mu_{t}=\mu_{t-1}+\eta_{t}, \quad \eta_{t} \sim N\left(0, \sigma_{\eta}^{2}\right) \\
& X_{t}=\beta X_{t-1}+\zeta_{t}, \quad \zeta_{t} \sim N\left(0, \sigma_{\zeta}^{2}\right) \\
& \gamma_{t}=-\sum_{j=1}^{s-1} \gamma_{t-j}+\omega_{t}, \quad \omega_{t} \sim N\left(0, \sigma_{\omega}^{2}\right)
\end{aligned}
$$

Where:

$$
\begin{aligned}
& E\left[\varepsilon_{t} \eta_{s}\right]=E\left[\varepsilon_{t} \zeta_{s}\right]=E\left[\varepsilon_{t} \omega_{s}\right]=0, \forall t, s . \\
& E\left[\varepsilon_{t} \alpha_{0}\right]=E\left[\eta_{t} \alpha_{0}\right]=E\left[\zeta_{t} \alpha_{0}\right]=E\left[\omega_{t} \alpha_{0}\right]=0, \forall t . \\
& \alpha_{t}=\left(\mu_{t}, X_{t}, \gamma_{t}, \gamma_{t-1}, \ldots, \gamma_{t-10}\right)^{\prime}, \quad \text { where } \alpha_{0} \sim N\left(a_{0}, P_{0}\right)
\end{aligned}
$$

Considering the monthly series, we have the following representation in State Space:

$$
\gamma_{t}=\underbrace{\left[\begin{array}{llllll}
1 & 1 & 1 & 0 & \cdots & 0
\end{array}\right]}_{Z_{t}} \underbrace{\left[\begin{array}{c}
\mu_{t} \\
X_{t} \\
\gamma_{t} \\
\gamma_{t-1} \\
\vdots \\
\gamma_{t-10}
\end{array}\right]}_{\alpha_{t}}+\varepsilon_{t} \sim N(0, \underbrace{\sigma_{\varepsilon}^{2}}_{H_{t}})
$$

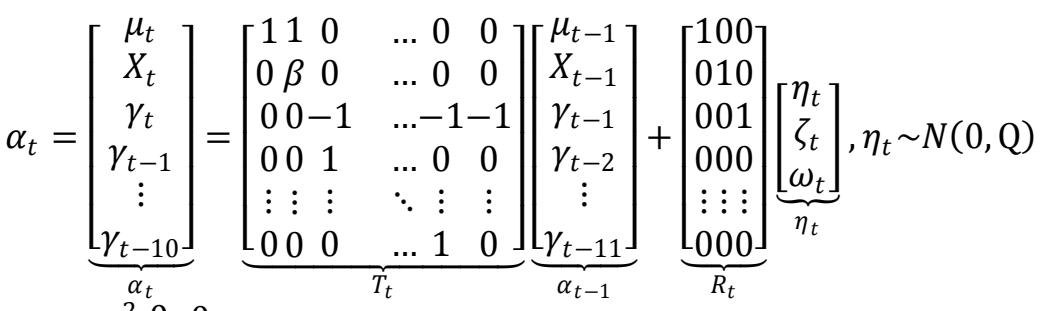

$$
\begin{aligned}
& \mathrm{Q}=\left[\begin{array}{ccc}
\sigma_{\eta}^{2} & 0 & 0 \\
0 & \sigma_{\zeta}^{2} & 0 \\
0 & 0 & \sigma_{\omega}^{2}
\end{array}\right]
\end{aligned}
$$

$y_{t}=$ Personal accident insurance for passengers (In million RS\$) in period $\mathrm{t}$

$x_{t}=$ Unoccupied people in period $\mathrm{t}$

$\varepsilon_{t}, \eta_{t}$ and $\kappa_{t}=$ Waste or shocks of the equations (1,2 and 3) 
$\beta=$ coefficient to be estimated via Kalman Filter

We have introduced three dummies into the model to accommodate the outliers. For this, we performed a pulse intervention by inserting factors $\lambda_{j t}$ that explain the effects of the dummies:

$D_{1, t}=\left\{\begin{array}{l}0, \text { tot } \neq 2014 / 11 \\ 1, \text { tot }=2014 / 11\end{array}\right.$

$D_{2, t}=\left\{\begin{array}{l}0, \text { tot } \neq 2014 / 12 \\ 1, \text { tot }=2014 / 12\end{array}\right.$

$D_{3, t}=\left\{\begin{array}{l}0, \text { tot } \neq 2015 / 12 \\ 1, \text { tot }=2015 / 12\end{array}\right.$

The key to dealing with the Structural Model is its placement in form in State Space (Equations 5 and 6). In this model the components are estimated recursively through the Kalman Filter ${ }^{17}(\mathrm{KF})$ or more completely using the smoothing algorithm. For more details on structural models, state space shape, Kalman Filter and smoothing algorithms check: Harvey (1989) and Durbin and Koopman (2001).

\section{Econometric study between the growth of private passenger transport start-ups and theunemployment} increase

As mentioned above, this article aims to study the relationship between the growth of unemployment and the rise of private passenger transport start-ups in Brazil. For this purpose, a sample of 83 data was obtained, provided by IBGE and SUSEP, which represents the period from March 2012 to January 2019.

Graphs 8 and 9: Series used for the model application.
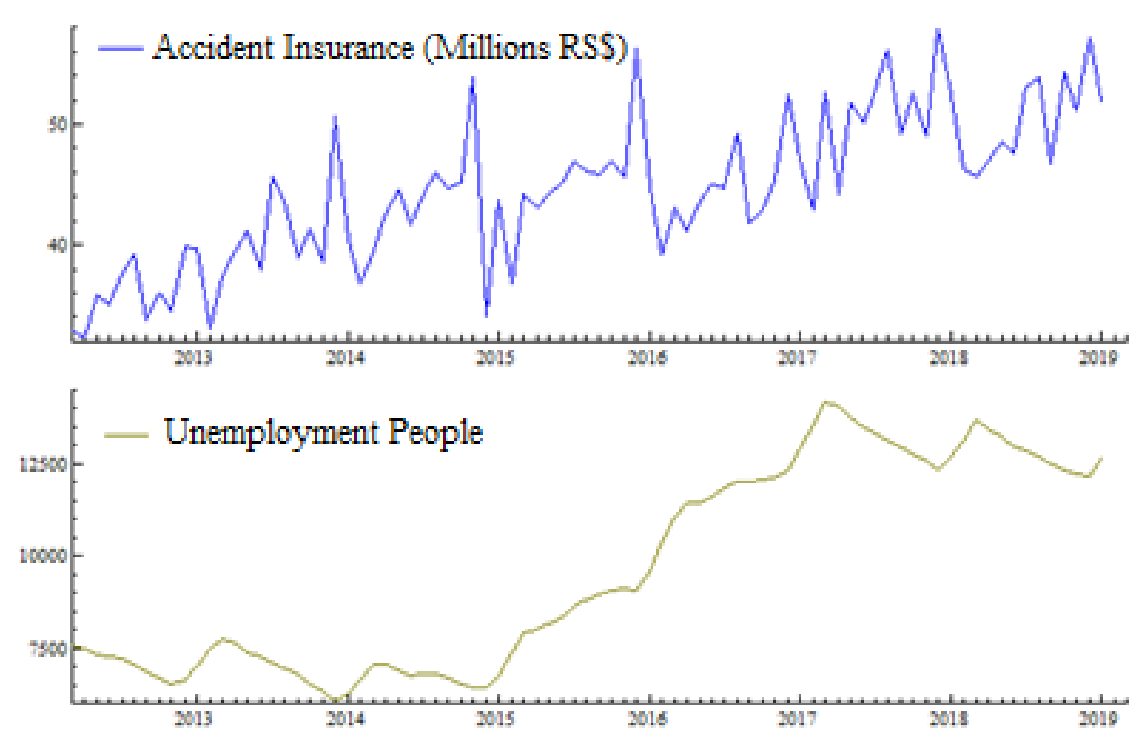

Source: Own preparation with data from IBGE and SUSEP

Table 2: Annual data

\begin{tabular}{l|l|l}
\hline Period & $\begin{array}{l}\text { Accident Insurance } \\
\text { (volume in millions of } \\
\text { Reais ) }\end{array}$ & $\begin{array}{l}\text { Unemployment } \\
\text { People }\end{array}$ \\
\hline 2013 & 487,51 & $84.432,00$ \\
\hline 2014 & 513,37 & $80.408,00$ \\
\hline 2015 & 545,09 & $100.301,00$ \\
\hline 2016 & 533,38 & $137.925,00$ \\
\hline 2017 & 606,52 & $158.971,00$ \\
\hline 2018 & 603,70 & $153.932,00$ \\
\hline Variations & & \\
\hline
\end{tabular}

${ }^{17}$ The STAMP software was used for the application of the proposed model 


\begin{tabular}{l|l|l}
$2017 / 2016$ & $13,7 \%$ & $15,3 \%$ \\
\hline $2018 / 2017$ & $-0,5 \%$ & $-3,2 \%$ \\
\hline Source: own preparation with data from IBGE and SUSEP
\end{tabular}

As can be seen in Table 2, compared to 2016, in 2017 the volume in millions of Reais in Accident Insurance grew $13.7 \%$ while the volume of unemployed people grew 15.3\%. In 2018, in comparison with 2017 both series showed a decrease in their volumes. According to Graphs 8 and 9, the volume of unoccupied people and the rise of private passenger transport start-ups (Personal Accident Insurance as proxy) presented a long-term growth trend, the rise of private transport start-ups with a greater variability compared to unemployment.

Graph 10 presents the Cross-Correlation Function between the volume, in millions of Reais, in Personal Accident Insurance for passengers and the volume of Unoccupied Persons, supplied by IBGE.

Graph 10: Cross- Correlation Function

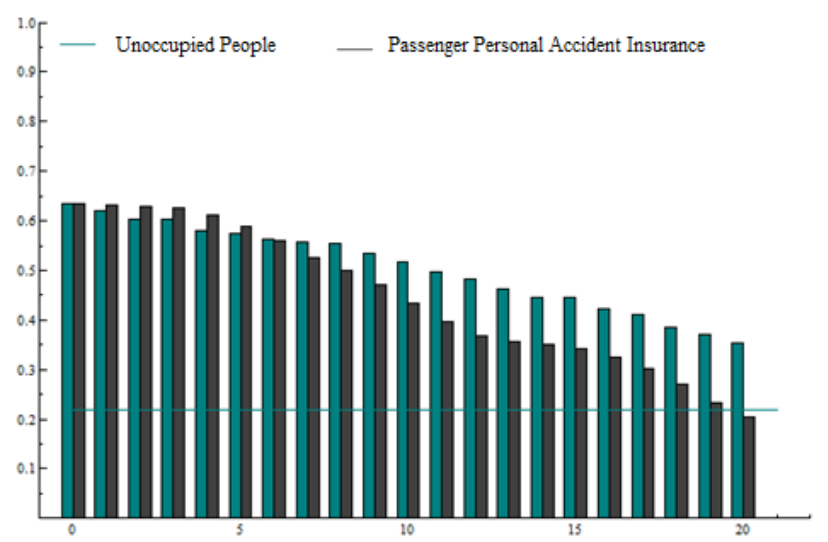

Source: own preparation with data from IBGE and SUSEP

As seen in Graph 10, the correlations between the variables are positive for the 20 lags analyzed. This positive correlation gives us evidence that the volume in millions of Reais in passenger personal accident insurance and the volume of unoccupied people move in the same direction in all analyzed periods. Based on the Cross-Correlation Function, it is possible to verify that the strongest correlation (around 0.6) occurs in time (t-1), and that it decreases along the horizontal axis.

Table 3: Estimated components using the exact likelihood principle.

\begin{tabular}{l|l}
\hline Variable & Estimation \\
\hline Level $\left(\sigma_{\eta}^{2}\right)$ & 0.931 \\
\hline Regression $\left(\sigma_{\zeta}^{2}\right)$ & 0.054 \\
\hline Seasonality $\left(\sigma_{\omega}^{2}\right)$ & 0.000 \\
\hline & \\
$\begin{array}{l}\text { Irregular } \\
\text { component }\left(\sigma_{\varepsilon}^{2}\right)\end{array}$ & 2.989 \\
\hline
\end{tabular}

Source: Own preparation in STAMP software.

As we observe in Table 3, the low value of the variance of the seasonal component gives us indications that this component can be considered non stochastic. Thus, we could disregard the term stochastic $\omega_{-} t$ and we would have similar results. It is important to complement the above study by checking the significance of the components as well as the seasonal terms (Table 3 ). 
Table 4: Estimators' significance

\begin{tabular}{c|c|c}
\hline \multicolumn{3}{|c}{ Components } \\
\hline Comp. & Test Statistics & P-value \\
\hline Level & 44, & {$[0.00000]$} \\
\hline Regression & 0,0097 & {$[0.02663)$} \\
\hline Seasonality & 13,699 & {$[0.00000]$} \\
\hline \multicolumn{3}{|c}{ Seasonality Components } \\
\hline Period & Test Statistics & P-value \\
\hline 1 & $-0,59619$ & {$[0.00614]$} \\
\hline 2 & $-1,76560$ & {$[0.00122]$} \\
\hline 3 & 1,26929 & {$[0.00019]$} \\
\hline 4 & $-1,48748$ & {$[0.00006]$} \\
\hline 5 & $-0,10561$ & {$[0.72479]$} \\
\hline 6 & $-2,11586$ & {$[0.00000]$} \\
\hline 7 & 0,20423 & {$[0.48705]$} \\
\hline 8 & $-0,76207$ & {$[0.01232]$} \\
\hline 9 & $-0,15728$ & {$[0.59977]$} \\
\hline 10 & $-2,08851$ & {$[0.00000]$} \\
\hline 11 & $-0,24202$ & {$[0.24420]$} \\
\hline
\end{tabular}

Source: Own preparation onSTAMP software.

As can be seen in Table 4, the hypothesis that the three components are not significant at the 5\% level is rejected, which indicates that the level, regression ${ }^{18}$ and seasonality components are significant.We also found as nonsignificant the seasonal terms of period 5, 7, 9 and 11 .

Graphs 11 and 12 present the breakdown of the volume in millions of Reais in personal accident insurance for passengers in the level component and in the seasonal component, both softened, having as an additional component (Equation 3) the volume of Unoccupied Persons.

Graphs 11 and 12: Level and Seasonality Components
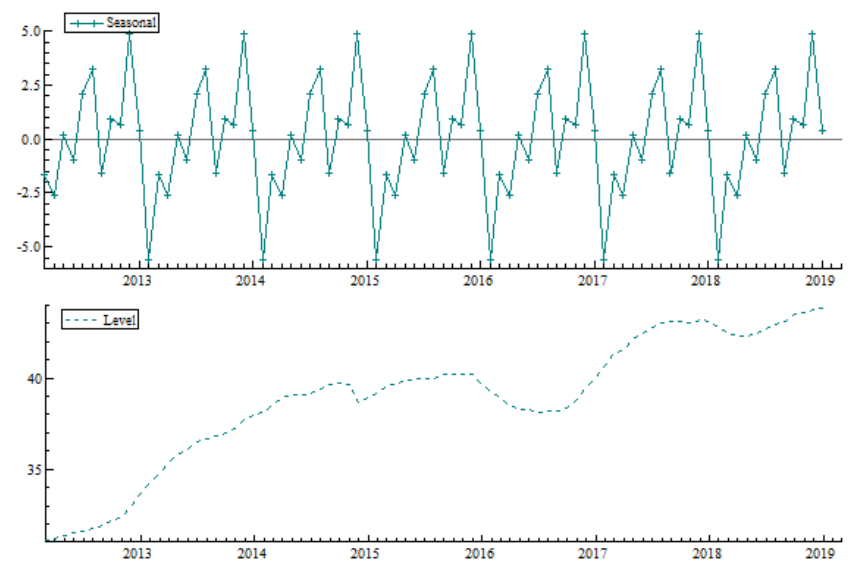

According to Graph 11, the seasonal factor relevant to the volume in millions of Reais in personal accident insurance for passengers can be considered deterministic. Its range goes from approximately -0.5 to 0.5 , being in December its highest peak and February as its lowest. When analyzing Table 1, we observe that the vacancy rate in the last quarter of the analyzed years showed increases compared to the first quarter of all years (2012 to 2019), thus indicating a possible seasonal movement. Other reasons can be associated with this type of movement in the analyzed series. Two reasons to be considered are holidays and end-of-year festivities that increase the demand for urban locomotion, making the market more attractive to drivers. As can be seen in Graph 12, the long-term component (The level) showed sharp growth over the period under review. Only in 2016 was there a sharper fall, it should be noted that in this period several demonstrations ${ }^{19}$ and acts of violence against the private passenger transport service occurred throughout the country, which generated discomfort both for drivers and passengers.

\footnotetext{
${ }^{18}$ A model without the regression component was also applied. According to $\mathrm{R}^{\wedge} 2$ and the BIC and CTA evaluation criteria the model obtained a worse fit than that presented in Table 3.

${ }^{19}$ See the main information agencies in the country, as: BBC, Folha de São Paulo, Estadão, O Globo, Correio Brasiliense and Veja Magazine.
} 
Graphs 13 and 14: Waste and Auto Correlation Function of Waste.
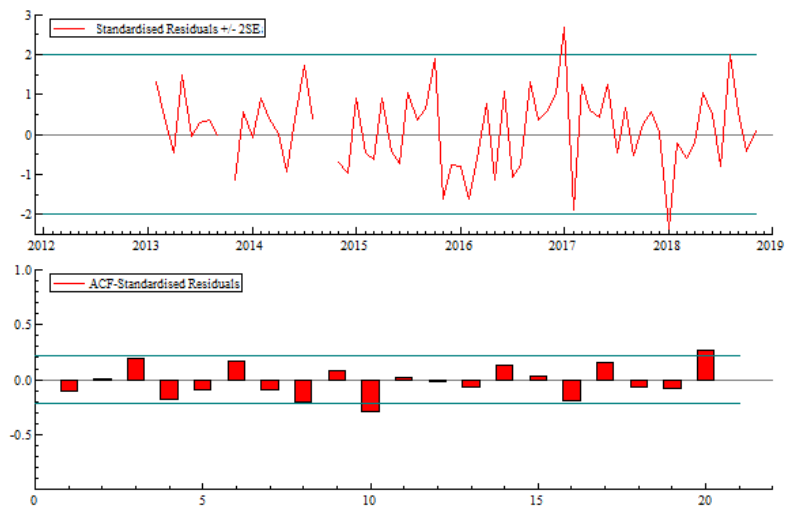

Source: Own preparation in STAMP software.

Table 5 presents the statistical tests applied to the model residues.

Table 5: Model evaluation criteria

\begin{tabular}{ll}
\hline Tests applied to the model residues \\
\hline Autocorrelated test (Durbin Watson) & 2,1495 \\
\hline Normality test & 0,3570 \\
\hline heteroscedastic test (22) & 1,5400 \\
\hline
\end{tabular}

Source: Own preparation in STAMP software.

According to Table 5 and Graphs 13 and 14, the residues are not autocorrelated and heteroscedastic. As the test results show, the hypothesis of normality was not violated. This behavior is common in models using time series, says Wooldridg (2001). In agreement with Durbin and Koopman (2001), normality of waste is desirable, but not essential for models in State Space. The results of the residual tests are satisfactory and there is no need to implement other dependency structures.

\section{Conclusion}

This study was carried out in order to study the rise of private passenger transport start-ups and their relationship with the increase in unemployment rates in Brazil.

As a reflection of an increasingly technological society, agents are becoming more "connected", quickly and continuously, to each other. The addition of information technology to private transport services has brought together providers (drivers) and demanders (passengers) of urban travel services. The rise of private passenger transport start-ups makes the market more competitive and tends to bring benefits to consumers of such services. Consecutively improving the welfare of society.

Data on the popularity of applications in the Brazilian states as of June 2019 (Figure 1) allow the territorial participation of private passenger transport start-ups to be assessed. It is notorious that start-ups are generally well spread throughout the country, although some companies are more popular than others. The Uber start-up is most sought after in the sub-regions: Brasília, Rio de Janeiro, São Paulo and Amazonas. The start-up 99 taxis showed more demand in the regions: Tocantins, Roraima, Rio de Janeiro and São Paulo. The agents are looking for the 99 pop app with more intensity in Amazonas, Ceará, Roraima and Distrito Federal. The Cabify start-up, showed more interest in the sub-regions: Rio Grande do Sul, Distrito Federal, Rio de Janeiro and Minas Gerais. The data points out that, when it comes to the laws of the market, the repressed demand for quality transportation of Brazilians was largely met by the private services of the start-ups studied, taking into account those who can pay for this type of service.

Rise of private passenger transport start-ups meets needs such as cost reduction and sustainability. This system reduces environmental impacts since in a five-seater car, at least four agents could be in different cars, consuming and polluting the atmosphere substantially. In addition, spending on fuel, parking, insurance and maintenance can be decreased.

During the unemployment generated by the economic crisis, part of the idle working class can shift their workforces to the provision of services, specifically the driving of private passenger transport vehicles. To investigate the above-mentioned relationship, this study proposes to investigate the rise of start-ups in Brazil and unemployment (rate of eviction of the population) in the same period. For the fundamentals of the study we use the models in State Space. 
The estimates pointed out that the hypothesis raised in this article cannot be disregarded, since the beta associated with the explanatory competition (Skilled people for work and temporarily unemployed) proved to be significant. The model presented a good adjustment, as can be seen in Section 4. However, we cannot rule out the influence of other variables for the ascension of start-ups in Brazil, some of which are the technological advance and the precariousness of the national transportation system.

The survey presented data and statistics that reveal and weigh the factors that boosted the rise of private passenger transport start-ups, such growth makes it essential to discuss the regulation of this market and urban policies.

\section{References}

99. Proteção contra acidentespessoais. Avaiable at:<https://99app.com/seguranca/>Access in: 10 may 2019.

ADRIAANSE, Mark Lievisse. Profits and Precarity: Uber and the Crisis of Work. Leiden University - Leiden, PaísesBaixos, 2016. Available at

: $<$ https://www.academia.edu/22355605/Profits_and_Precarity_Uber_and_the_Crisis_of_Work>Access in:19 june 2019.

ANATEL. Telefoniamóvel - acessos. Avaiable at: $<$ http://www.anatel.gov.br/dados/acessos-telefoniamovel>Access in: 16 june 2019.

BERGER, Thor; FREY, Carl Benedikt; LEVIN, Guy; DANDA, Santosh Rao. Uber Happy? Work and Wellbeing in the "Gig Economy". Working paper to be presented at the 68th Panel Meeting of Economic Policy in October 2018. Oxford Martin School, University of Oxford - Oxford, Inglaterra, 2018. Avaiable at:<https://www.oxfordmartin.ox.ac.uk/downloads/academic/201809_Frey_Berger_UBER.pdf >Access in: 19 june 2019.

CABIFY. Cláusula terceira - obrigações e responsabilidades do condutor. Available at: <https://cabify.com/brazil/terms>Access in: 10 may 2019.

CASTRO, As Carlo Antonio Atocha. Las plataformas virtuales. Análisisdel caso UBER ¿Una nuevamodalidad de contrataciónlaboral?.Universidad de Piura. Facultad de Derecho. Programa Académico de Derecho Piura, Perú, 2017. Avaiable at:

<https://pirhua.udep.edu.pe/bitstream/handle/11042/2926/DER_102.pdf?sequence=1\&isAllowed=y >Acces $\mathrm{s}$ in: 17 june 2019.

CNDL/SPC BRASIL. Serviços de transporte por aplicativos. Brasília, 2017. Avaiable at:<https://www.spcbrasil.org.br/wpimprensa/wp-content/uploads/2018/01/An\%C3\%A1lise-S >Access in: 23 march 2019.

DEE/CADE. Competition Effects of the Sharing Economy in Brazil: Has Uber's entry affected the cab-hailing app market from 2014 to 2016?.Departamento de Estudos Econômicos - DEE, Brasília/DF, 2018. Avaiable at:<http://en.cade.gov.br/topics/about-us/dee/working-paper-uber_01-2018.pdf>Access in: 30 may 2019.

. O Cade. Avaiable at:< http://www.cade.gov.br/acesso-a-informacao/institucional >Access in: 30 may 2019.

DURBIN, James.; Koopman, Siem Jan Durbin, and Koopman. Time Series Analysis by Space State Methods. Oxford University Press, 2001.

ECGLOBAL. 66\% of Brazilian Internet users have already used UBER, points out study from eCMetrics and eCGlobal. Avaiable at:<http://ecmetrics.com/usage-perception-uber-brazil/>Access in: 29 may 2019.

FIGUEIRA, Gabriel Mendes. Mobilidade colaborativa no Brasil: um estudo de caso sobre as iniciativas de carona na economia colaborativa. XI Congresso Nacional de excelência em gestão, 2015. Avaiableat:<http://www.inovarse.org/sites/default/files/T_15_027M_3.pdf>Access in: 26 march 2019.

GODINHO, Hélio Ferreira; LINOS, Cleisson Geraldo dos Santos; OLIVA FILHO, Oliver de Oliveira. Uma abordagem sobre a tecnologia 4G LTE e sua aplicação no Brasil. Revista Científica Semana Acadêmica, Fortaleza, 2018, №. 000120, 19/03/2018. Avaiable at: <https://semanaacademica.org.br/system/files/artigos/4glte_0.pdf>Access in: 29 may 2019.

GONÇALVES, Camila Lustoza Romero. As plataformas de e-hailing presentes no ecossistema de mobilidade urbana no Brasil: um estudo de múltiplos casos. Rio de Janeiro, 2016. Avaiable at:<https://www.coppead.ufrj.br/upload/publicacoes/Camila_Goncalves.pdf>Access: 05 april 2019.

GOOGLE TRENDS. Avaiable at:<ttps://trends.google.com.br/trends/>Access in: 30 may 2019.

HARVEY, Andrew. C. A Forecasting, Structural Time Series Models and the Kalman Filter.1. ed. Cambridge Univ. Press, Cambridge, 1989.

HALL, Jonathan D.; PALSSON, Craig; PRICE, Joseph. Is Uber a substitute or complement for public transit?.USA, 2018. Avaiable at:<http://www.palssonresearch.org/Uber_and_Public_Transit.pdf $>$ Access in: 05 april 2019.

IBGE. O IBGE. Avaiable at:<https://www.ibge.gov.br/institucional/o-ibge.html>Access in: 30 may 2019. 
Pesquisa Nacional por Amostra de Domicílios Contínua - PNAD Contínua. Séries históricas. Avaiable at:<https://www.ibge.gov.br/estatisticas/sociais/trabalho/9171-pesquisa-nacional-por-amostra-dedomicilios-continua-mensal.html?edicao=20652\&t=series-historicas $>$ Access: 17 june 2019.

Pesquisa Nacional por Amostra de Domicílios Contínua: Trimestre móvel jan. - mar. 2019. IBGE, 2019. Avaiable at:<https://biblioteca.ibge.gov.br/visualizacao/periodicos/3086/pnacm_2019_mar.pdf >Access in: 30 may 2019.

JUNIOR, Ricardo Mendes; FUSCO, Rafael. Projeto carona solidária na UFPR. Paraná: UFPR, 2013. Avaiable at:<https://revistas.ufpr.br/extensao/article/view/35664/22002> Access in: 05 may 2019.

LEAL, Túlio Augusto Castelo Branco. Aspectos legais e econômicos dos serviços de transporte individual de passageiros - Táxis, Uber e serviços assemelhados. Brasília: Núcleo de Estudos e Pesquisas/CONLEG/ Senado, 2016 (Texto para Discussão $n^{\circ}$ 212). Avaiable at:<www.senado.leg.br/estudos>Access in: 18 march 2019.

LENZ, Éverton Luís. Projeto e desenvolvimento de aplicação para melhoria de serviços de transporte urbano. Lajeado, 2017. Avaiable at: <https://www.univates.br/bdu/bitstream/10737/1673/1/2017EvertonLuisLenz.PDF> Access in: 05 april 2019.

LOPES, Caroline Albuquerque. Qualidade de vida no trabalho em atividades de serviços e transporte por aplicativos: um estudo de caso na empresa Uber. Mariana, 2017. Avaiable at: $<$ http://monografias.ufop.br/bitstream/35400000/933/1/MONOGRAFIA_QualidadeTransporteAplicativ os.pdf>Access in: 18 march 2019.

MEANS, Benjamin; SEINER, Joseph A. Navigating the Uber Economy. South Carolina, EUA, 2016. Avaiable at:<https://onlabor.org/wp-content/uploads/2017/01/49-4_Means_Seiner.pdf>Access in: 05 april 2019.

PEREIRA, Geissiele Gonçalves; MAIA, Katy; GOMES, Magno Rogério. A composição do desemprego no Brasil de 2012 a 2016/2017:uma abordagem regional. Londrina, 2018. Avaiable at: <https://www.anpec.org.br/sul/2018/.../33-732a365028163b790704defb5806f05a.pdf>Access in: 22 april 2019.

PUGLIESE, Carlotta Maria Barracosa.Creating value with digital platforms - the cases of Uber and Airbnb. Rio de Janeiro, 2016. Avaiable at:

<https://bibliotecadigital.fgv.br/dspace/bitstream/handle/10438/18000/THESIS\%20CARLOTTA\%20\%20FGV\%20-\%20biblioteca.pdf>Access in: 05 april 2019.

RIBEIRO, Flávio Barberino; PINHEIRO, Lessi Inês Farias. Crescimento econômico e de desemprego na Bahia: referencial teórico e evidências empíricas. Universidade Estadual de Santa Cruz - UESC, Ilhéus - Bahia, 2015. Avaiableat:<www.uesc.br/eventos/vsemeconomista/anais/gt1-3.pdf>Access in: 10 may 2019.

RIBEIRO, Hugo Alves Silva; BERARDINELLI, Leonardo Moy Alves; PEIXOTO, Nathane Eva Santos. Uber: Transporte para complementação de renda. Brasília, 2018. Avaiable at: <https://www.researchgate.net/profile/Hugo_Ribeiro27/publication/326160920_Uber_transporte_para_co mplementacao_de_renda/links/5b3bdfa5a6fdcc8506eebf24/Uber-transporte-para-complementacao-derenda.pdf>Access in: 18 march 2019.

RIBEIRO, Luiz Alberto Pereira; DUARTE, Francisco Carlos. A globalização e a crise do desemprego: política de austeridade como solução para a crise do desemprego na europa. Paraná, 2015. Avaiable at:<www.periodicos.ufc.br/nomos/article/download/1304/4454>Access in: 22 april 2019.

RODRIGUES, P.L. Empreendedorismo no Brasil: um olhar sobre as startups. Trabalho de conclusão submetido ao Curso de Graduação em Ciências Econômicas da Faculdade de Ciências Econômicas da Universidade Federal do Rio Grande do Sul. 2016.

ROMERO, Yasmín Hernández; SOSA, Raúl Vicente Galindo. Modelo de gestióndelservicio de transporte UBER. ¿Quiénpierde y quiéngana?.Espacios Públicos, Vol. 19, Núm. 47, setembro-dezembro, 2016, Pág. 157-175, Universidad Autónoma del Estado de México - Toluca, México. Avaiable at:<http://www.redalyc.org/articulo.oa?id=67650281008>Access in: 17 june 2019.

SILVA, Diane Bianchi da Costa e. Transporte solidário: uma rede colaborativa para cidades mais sustentáveis. Rio de Janeiro: Escola Politécnica, UFRJ, 2015. 62 p. Trabalho de Conclusão - 2015. Avaiable at: $<$ http://www.peu.poli.ufrj.br/arquivos/Monografias/DIANE_BIANCHI.pdf $>$ Access in: 05 may 2019.

SILVA, Laize Andréa de Souza; ANDRADE, Maurício Oliveira de. Conflitos de regulação entre os serviços de táxis e o Uber no Brasil: sem foco na qualidade da mobilidade urbana. Pernambuco, 2016. Avaiable at: $<$ https://docplayer.com.br/75882942-Conflitos-de-regulacao-entre-os-servicos-de-taxis-e-o-uber-nobrasil-disputa-de-mercado-sem-foco-na-qualidade-da-mobilidade-urbana.html>Access in: 12 april 2019.

STATISTA. Number of users of selected taxi apps in Brazil as of 2018 (in millions). Avaiable at:< https://www.statista.com/statistics/887289/brazil-taxi-app-number-users/>Access in: 19 june 2019. Brazil: Total population from 2012 to 2022 (in million inhabitants). Avaiable at: <https://www.statista.com/statistics/263763/total-population-of-brazil/>Access in: 19 june 2019.

SUSEP. O que é o Seguro de Acidentes Pessoais de Passageiros?.Avaiable at: $<$ http://www.susep.gov.br/menu/informacoes-ao-publico/planos-e-produtos/seguros/informacoesuteis>Access in: 22 april 2019. 
. SES - Sistema de Estatística da SUSEP.Opção escolhida: Seguros: Prêmios e Sinistros. Avaiable at:<http://www2.susep.gov.br/menuestatistica/SES/principal.aspx>Access in: 22 april 2019.

UBER. Informações para motoristas. Avaiable at:<https://www.uber.com/pt-BR/blog/como-funciona-segurouber-para-motoristas-parceiros-usuarios/> Access in: 22 april 2019.

VACLAVIK, Marcia C.; PITHAN, Liana H. The agency search: the meaning of work for app. Revista de Administração Mackenzie, 19(5). doi:10.1590/1678-6971/eRAMG180080. Universidade Federal do Rio Grande do Sul (UFRGS) - Porto Alegre, 2018. Avaiable at:<http://www.scielo.br/pdf/ram/v19n5/16786971-ram-19-05-eRAMG180080.pdf>Access in: 19 june 2019.

WOOLDRIDGE, Jeffrey, Marc. Applications of generalized method of moments estimation. Journal of Economic perspectives, 15(4), pp.87-100. 2001. 